\title{
Современные подходы к теоретическому обоснованию защиты государственного суверенитета
}

\author{
Красинский В. В., \\ доктор юридических наук, профессор, \\ член Общественного консультативного научно-методического Совета \\ при Центральной избирательной комиссии Российской Федерации \\ e-mail: rjls@bk.ru
}

Аннотация. В статье рассматриваются актуальные угрозы государственному суверенитету, основные механизмы его ослабления и подрыва. Автор анализирует деструктивную деятельность антигосударственных сил по ослаблению и подрыву государственного суверенитета и обосновывает необходимость защиты государственного суверенитета. Ключевье слова: государственньй суверенитет, защита государственного суверенитета, угрозы государственному суверенитету, факторы ослабления и подрыва государственного суверенитета, механизмы ослабления и подрыва государственного суверенитета, антигосударственные сильь.

$\Gamma$ осударственный суверенитет как способность государства самостоятельно решать любые внутри- и внешнеполитические задачи, обеспечивать реализацию своих властных полномочий в отношении всех субъектов права в пределах своей территориальной юрисдикции является динамичной характеристикой государства. Его необходимо завоевывать и все время защищать. Государственный суверенитет может быть подорван и утрачен. Как справедливо отмечает С. А. Авакьян, «о своем - государственном - суверенитете обязано заботиться любое государство» ${ }^{1}$

Учитывая предложенный подход к пониманию государственного суверенитета, его защита представляет собой постоянную активную правомерную деятельность государственных и негосударственных организаций, направленную на обеспечение верховенства и независимости государственной власти, беспрепятственную реализацию государственно-властных полномочий в наиболее важных сферах общественной жизни, противодействие деструктивной деятельности антигосударственных сил по ослаблению и подрыву государственного суверенитета.

Основанием защиты государственного суверенитета выступает деструктивная деятельность внутригосударственных и зарубежных субъектов по его ослаблению и подрыву. Подобную деятельность можно определить как постоянную спланированную подрывную деятельность государственных органов и негосударственных структур иностранных государств, внутренних антигосударственных сил, осуществляемую в нарушение Конституции и других законов государ-

\footnotetext{
1 Авакьян С. А. Точка отсчета - народ // Российская газета. 2006. 28 октября.
}

ства в целях снижения качественных характеристик и способности государства реализовывать свои функции в наиболее важных сферах общественной жизни, смены политического режима и поддержки принятия выгодных антигосударственным силам политических решений.

Анализ внешних проявлений деструктивной деятельности по ослаблению и подрыву государственного суверенитета позволяет выделить ряд ее особенностей.

1. Ослабление и подрыв государственного суверенитета возникают не естественным образом, а в результате целенаправленной, тщательно спланированной и организованной деятельности внешних и внутренних антигосударственных сил ${ }^{2}$.

Антигосударственные силы следует рассматривать как совокупность государственных и негосударственных организаций иностранных государств и внутригосударственных структур, принимающих участие в планировании, финансировании, информационно-пропагандистском, оперативном, аналитическом, ресурсном и боевом обеспечении, организации и непосредственном осуществлении деструктивной деятельности по ослаблению и подрыву государственного суверенитета.

Зарубежные субъекты в современных условиях представлены органами государственной власти, спецслужбами, воинскими формированиями, органами внешних сношений, кредитно-финансовыми учреждениями. Эти структуры планируют, организуют, координируют, финансируют и обеспечивают деструктивную

\footnotetext{
2 Данная методологическая оговорка имеет важное значение, поскольку ослабление государственного суверенитета может быть следствием естественно-исторических процессов.
} 
деятельность по ослаблению и подрыву государственного суверенитета. Для непосредственного осуществления и сопровождения указанной деятельности привлекаются СМИ, иностранные фонды, религиозные, научные, националистические, неправительственные и иные организации, участвующие в политической жизни иностранного государства.

Функции общего руководства антигосударственной деятельностью в зарубежных странах осуществляет глава исполнительной власти (президент или премьер-министр, в зависимости от формы правления в государстве). Свои полномочия он, как правило, реализует через подведомственные органы (советы национальной безопасности, постоянные комитеты в составе кабинета министров и др.). В ряде случаев, предусмотренных законодательством, решения высшего должностного лица органа исполнительной власти согласуются с парламентом.

Основным зарубежным элементом антигосударственной деятельности являются спецслужбы иностранных государств, которые действуют на правах самостоятельных ведомств (ЦРУ США, БНД ФРГ, Моссад Израиля, МИТ Турции) либо являются частью отраслевых органов управления (РУМО США, МАД ФРГ, АМАН Израиля, ГРУ Турции).

К числу внутригосударственных субъектов деструктивной деятельности необходимо отнести радикально настроенных представителей так называемой «несистемной оппозиции», организованных преступных формирований, националистических, сепаратистских, экстремистских и террористических структур, негосударственные организации различных организационно-правовых форм.

Активное использование при ослаблении и подрыве государственного суверенитета негосударственных организаций позволяет иностранным спецслужбам, с одной стороны, получать и приобретать необходимые прикрытия, расширять свои оперативные возможности, с другой - тщательно маскировать деятельность своего политического руководства и устремления в отношении страны-противника.

2. Эта деятельность направлена против государства, преследует цели ослабления и подрыва государственного суверенитета.

Терминологическая система теории защиты государственного суверенитета предполагает разграничение понятий «ограничение государственного суверенитета», «ослабление государственного суверенитета» и «подрыв государственного суверенитета».

Ограничение государственного суверенитета включает теоретическое обоснование, политико-правовое закрепление и практическую реализацию мер, уменьшающих полновластие государства (верховенство и независимость государственной власти).

В качестве ослабления государственного суверенитета предлагается рассматривать снижение качественных характеристик реализации функций государства в наиболее важных сферах общественной жизни. Ослабление государственного суверенитета может быть следствием естественно-исторических процессов (существенное снижение потенциала государства из-за экономических проблем, исчерпание полезных ископаемых, влияние глобализации), а также происходить в условиях специального целевого воздействия (организация или поддержка государственного переворота, понуждение к передаче части суверенных полномочий тем или иным военно-политическим блокам и др.). При ослаблении государственного суверенитета компетентные структуры не в состоянии осуществлять власть в полном объеме на всей территории государства в отношении всех субъектов права. Постепенно это приводит к деградации государственных институтов.

Подрыв государственного суверенитета характеризуется утратой способности государства реализовывать свои функции в наиболее важных сферах общественной жизни, осуществлять самостоятельное управление делами общества и государства. Подрыв государственного суверенитета не происходит случайно. Он всегда готовится и сопровождается. При подрыве государственного суверенитета прерогативы государственной власти целенаправленно присваиваются альтернативными структурами. В конечном счете органы государства перестают быть легитимными, утрачивают доверие и поддержку населения.

Ослабление и подрыв государственного суверенитета указывают на деструктивную направленность и характердеятельности илипроцессов, происходящих с государством и его властными институтами (отстранение от власти законно избранных должностных лиц, подрыв экономики, нарушение территориальной целостности). Эти процессы могут реализовываться на практике вне рамок правового поля и соответствующих процедур. Ограничение государственного суверенитета, как правило, имеет теоретико-правовые основания и позитивное целеполагание (развитие правового статуса личности, укрепление экономических и политических связей, прекращение преступной деятельности, привлечение государства-агрессора и виновных к ответственности). Ограничение государственного суверенитета предполагает обязательное наличие нормативных основ и юридического контроля за применяемыми по отношению к государству санкционными мерами.

Ослабление и подрыв государственного суверенитета осуществляются главным образом 
на плановой основе с участием антигосударственных сил. Для ограничения государственного суверенитета этот признак не характерен.

В современной международно-правовой практике ограничение государственного суверенитета завершается после прекращения государством противоправной деятельности (агрессия, геноцид и др.) и привлечения виновных лиц к ответственности.

В статье понятия «ограничение», «ослабление» и «подрыв» государственного суверенитета используются с учетом изложенных методологических установок.

3. Рассматриваемая деструктивная деятельность всегда носит противоправный характер, поскольку акции ослабления и подрыва государственного суверенитета нарушают нормы международного права, Конституцию и другие законы государства. Противоправные акции по ослаблению и подрыву государственного суверенитета могут планироваться, финансироваться, обеспечиваться и осуществляться на протяжении десятилетий и столетий (например, антигосударственная деятельность по «сдерживанию» России и развалу СССР) вне зависимости от политики государства и действий должностных лиц. В связи с необходимостью обоснования максимально возможного по продолжительности периода действия мер по ослаблению и подрыву государственного суверенитета данные меры в перспективе всегда претендуют на ограничительно-легальный характер.

Учитывая противоправность, одиозность и реакционность ослабления и подрыва государственного суверенитета, в современных условиях любые государства - участники военно-политического, экономического и идеологического противоборства стремятся придать своей деятельности по ослаблению и подрыву государственного суверенитета стран-противников легитимность, теоретически обосновать и информационно-пропагандистски обеспечить, узаконить ее, трансформировать ее в юридически обязывающие ограничительные меры.

4. Деструктивная деятельность внутригосударственных и зарубежных антигосударственных сил формирует реальные угрозы государственному суверенитету, масштабы и потенциал которых зависит от угрозообразующих факторов.

К наиболее опасным внутренним угрозам государственному суверенитету относятся:

- низкая конкурентоспособность национальной экономики;

- наращивание потенциала организованной преступности;

- коррупционная пораженность государственного аппарата;

- протестная активность и экстремистская деятельность структурных звеньев радикальной оппозиции;

- устойчивое функционирование вооруженного бандподполья на территории Северо-Кавказского региона и попытки переноса террористической деятельности в другие регионы Российской Федерации.

Низкая конкурентоспособность национальной экономики проявляется в технологическом отставании от ведущих стран, зависимости от поставок современного зарубежного оборудования и программных средств, невысокой производительности труда. Характерными угрозообразующими факторами являются:

- ориентация владельцев средств производства на максимальное извлечение прибыли, хищническую эксплуатацию рабочей силы и производственных фондов;

- отсутствие амортизационных отчислений на модернизацию оборудования, программных средств, переподготовку и повышение квалификации персонала;

- недостаточная степень либерализации инвестиций и заимствования передовых иностранных технологий;

- низкий уровень развития инфраструктуры (транспортной системы, телекоммуникаций, энергоснабжения, складского хозяйства и распределительной сети);

- остаточное финансирование НИОКР и инновационной деятельности;

- выезд за рубеж высококвалифицированных специалистов;

- недостаточно высокое качество менеджмента в бизнесе (конкурентные стратегии, управление финансами, кадрами, развитие продукта и контроль качества).

Низкие темпы перевода национальной экономики на инновационный путь развития актуализируют вопрос модернизации и повышения конкурентоспособности российской экономики. Автор поддерживает позицию профессора О. Д. Абрамовой в том, что решение этой масштабной задачи стратегического характера «поставило бы нашу страну по уровню благосостояния в ряд наиболее развитых стран и обеспечило ей достойные позиции в мире» ${ }^{3}$.

Масштабной угрозой государственному суверенитету становится наращивание потенциала организованной преступности за счет проникновения в органы власти, доступа к ключевым отраслям экономики и кредитно-финансовым учреждениям. Представители организованной преступности стремятся контролировать прибыльные секторы экономики, управлять бюджетными средствами, участвовать в приня-

\footnotetext{
3 Внешняя политика России: теория и практика / Под ред. С. В. Смульского и О. Д. Абрамовой. М.: Книга и бизнес, 2013. С. 147.
} 
тии решений органами власти, влиять на законотворческий процесс.

Роль преступных организаций (сообществ) в российской политической системе сегодня выражается в их функциях, к числу которых относятся:

а) представительство социально-политических интересов определенной части общества;

б) фактическое осуществление отдельных государственно-властных полномочий («теневая» юстиция, воспитание и трудоустройство подростков из неблагополучных семей и др.);

в) разработка и реализация политической стратегии и тактики борьбы за государственную власть в ходе выборов.

Существующая криминогенная ситуация усугубляется проводимой уголовно-правовой политикой. Современное состояние уголовно-правового законотворчества характеризуется хаотичным и противоречивым подходом к попыткам противодействия преступности, в рамках которого можно выделить ряд угрозообразующих факторов:

- освобождение от уголовной ответственности за совершение широкомасштабных экономических преступлений;

- отказ от реальной борьбы с незаконным обогащением путем конфискации;

- введение системы денежных штрафов, позволяющей пользоваться ею состоятельным гражданам, для освобождения от реального наказания в виде лишения свободы;

- имитация сокращения преступности путем декриминализации общественно опасных деяний.

Это означает выстраивание дискриминационной социальной системы в уголовно-правовой сфере на основе неравенства материальных возможностей граждан ${ }^{4}$.

Автор разделяет точку зрения А. Д. Керимова, по мнению которого «слабость государственных институтов, проявляющаяся в их неспособности регулировать и контролировать социальные процессы, в демонстрируемой ими беспомощности при необходимости решения разнообразных возникающих перед социумом задач, неизбежно ведет к тому, что эту роль стремятся взять на себя другие силы и структуры»5. Как правило, такими силами являются олигархические структуры и организованные преступные сообщества.

Слабое государство, не располагающее достаточными материальными и финансовыми ресурсами и средствами, не способно эффектив-

\footnotetext{
4 Дамаскин О. В. Криминологические аспекты формирования современной уголовно-правовой политики // Современное право. 2013. № 5.

5 Керимов А. Д. Государственная организация общественной жизнедеятельности. Вопросы теории. М.: Норма, 2014. С. 67.
}

ным образом регулировать экономику страны, должным образом перераспределять доходы, не в состоянии преодолеть неизбежно возникающее вопиющее социальное неравенство, справиться с унижающей человеческое достоинство бедностью, а зачастую и с грозящей вымиранием значительной части населения нищетой ${ }^{6}$. В этих условиях правящие круги подвержены искушению исправить сложившееся в экономической сфере бедственное положение, прибегнув не к цивилизованным формам и методам ее оздоровления, а к испытанному варварскому средству, т. е. развязыванию агрессивной, захватнической войны ${ }^{7}$.

В рассматриваемой системе внутренних угроз государственному суверенитету значительную опасность представляет коррупционная пораженность государственного аппарата.

Согласно статистическим данным, в 2012 г. в Российской Федерации зарегистрировано 49513 преступления коррупционной направленности. Большинство из них (90,1 \%), выявлено органами внутренних дел. Удельный вес преступлений коррупционной направленности в структуре преступности в Российской Федерации составляет 2,2 \%. В то же время доля ущерба от коррупционных преступлений достигает 7,8 \% (20 821800 ооо руб.) из суммы ущерба от всей выявленной в стране преступности. Из числа преступлений коррупционной направленности, дела и материалы о которых находились в производстве в отчетный период, 75,8 \% (37 546) направлено в суд.

В 2012 г. было выявлено 13565 лиц, совершивших преступления коррупционной направленности ${ }^{8}$.

Как свидетельствуют материалы уголовной статистики, на основе коррупционной составляющей организованная преступная деятельность

\footnotetext{
6 Керимов А. Д. Указ. соч. С. 68.

7 Керимов А. Д. Указ. соч. С. 69. Примеры таких решений: вторжение вооруженных сил Грузии в Южную Осетию в 2008 г. и карательная операция вооруженных формирований Украины в отношении Новороссии в 2014-2015 гг.

8 Статистические данные ГИАЦ МВД России - «Сводный отчет по России о состоянии преступности и результатах расследования преступлений» (форма 494); «Сводный отчет по России о результатах работы правоохранительных (правоприменительных) органов по борьбе с преступлениями, совершенными с использованием служебного положения должностными лицами, государственными служащими и служащими органов местного самоуправления, а также лицами, выполняющими управленческие функции в коммерческой или иной организации» (форма 590); статистические сведения управления правовой статистики Генеральной прокуратуры Российской Федерации - «Сведения о работе прокурора по надзору за исполнением законодательства о противодействии коррупции и о результатах расследования уголовных дел о преступлениях коррупционной направленности» (форма К) за 2012 г.
} 
осуществляется при участии должностных лиц правоохранительных органов, сотрудничающих с криминальными структурами. При этом если ранее наиболее высокодоходные сферы незаконной деятельности находились под негласным контролем криминальных авторитетов, то в настоящее время наметилась тенденция к реализации преступных (в том числе коррупционных) схем руководителями крупных коммерческих организаций и должностными лицами органов государственной власти и управления.

Анализ структуры коррупционной преступности показывает рост удельного веса мошенничеств, совершенных с использованием служебного положения (с 23 \% в 2011 г. до $31 \%$ в 2012 г.). Из лиц, привлеченных к ответственности за совершение преступлений коррупционной направленности, большинство работали в исполнительных органах государственной власти на уровне субъекта Федерации - 57 \%; в органах местного самоуправления работали 21,6 \%, в органах государственной власти федерального уровня - 21,5\%. Среди работников правоохранительных органов, привлеченных к уголовной ответственности за коррупционные преступления, подавляющее большинство (63 \%) являлись сотрудниками органов внутренних дел 9

Следует констатировать, что к ответственности за коррупционные преступления привлекаются в основном представители низовых звеньев государственного аппарата и органов местного самоуправления. Удельный вес представителей органов государственной власти и управления среди осужденных взяткополучателей составляет менее 1 \%. Доля фактов взяточничества в крупном размере в общем числе выявленных - лишь $7,6 \%{ }^{10}$. Вместо привлечения к уголовной ответственности должностных лиц, допустивших хищение и нецелевое расходование бюджетных средств, злоупотребление полномочиями, получает распространение практика увольнения данных граждан с государственной службы или ротации на другие должности в государственном аппарате.

На коррупционную пораженность государственного аппарата влияют следующие факторы:

- несоответствие уровня заработной платы чиновников объему и сложности выполняемых должностных обязанностей;

- широкие пределы усмотрения чиновников при разрешении административных процедур;

- трудновыполнимые требования к граж-

\footnotetext{
9 Состояние законности и правопорядка в Российской Федерации и работа органов прокуратуры. 2012 год: информационно-аналитическая записка / Под общ. ред. ректора Академии Генеральной прокуратуры Российской Федерации, д. ю. н., проф. О. С. Капинус. М., 2013. 343 с.

10 Дамаскин О. В. Коррупция: состояние, причины, противодействие. М.: Триумфальная арка, 2009. С. 32.
}

данам и организациям, создающие условия для коррупционных проявлений;

- возможность необоснованного применения преференций в отношении избранных субъектов права;

- отсутствие надежных правовых гарантий неукоснительного исполнения законов всеми субъектами права, защиты прав собственников и представителей бизнеса;

- различные подходы антикоррупционных законов к оценке материального положения, источников доходов, законности и прозрачности расходов отдельных должностных лиц и правовым последствиям конфликта интересов у данных лиц, непредставления этими должностными лицами сведений о доходах, расходах, имуществе и обязательствах имущественного характера в установленные сроки, а также представления заведомо недостоверных или неполных сведений;

- наличие иммунитетов и изъятий из общего порядка уголовного судопроизводства у ряда должностных лиц федерального, регионального и муниципального уровня.

Перечисленные угрозообразующие факторы дискредитируют органы власти и управления в глазах населения, стимулируют нарушение законных интересов граждан и организаций, негативно влияют на осуществление государственных функций.

Относительно новой угрозой государственному суверенитету можно назвать протестную активность и экстремистскую деятельность структурных звеньев радикальной оппозиции.

В отличие от легальной оппозиции, осуществляющей свою деятельность в рамках существующего законодательства, радикальная оппозиция преследует цели насильственного изменения конституционного строя и не ограничивает арсенал своих методов, средств и источников финансирования. Лидерами и функционерами данных структур используются различные угрозообразующие факторы, в числе которых выступают:

- принятие государственными органами непопулярных политических решений в социально-экономической сфере (реформирование ЖКХ, пенсионная реформа, система налогообложения и др.);

- наличие очагов социальной напряженности в регионах с высоким уровнем безработицы и неблагоприятной криминогенной обстановкой;

- снижение уровня благосостояния населения, девальвация национальной валюты и рост цен из-за санкционного давления США и стран Евросоюза;

- проблемы и недостатки антикриминальной и антикоррупционной политики государства и др. 
Существующие социально-экономические трудности используются для организации и координации различного рода протестных акций («антикризисных маршей», «антивоенных маршей», «маршей несогласных», «антикоррупционных протестов» и др.), дестабилизации общественно-политической ситуации и смены государственно-политического режима по сценариям «цветных» революций. На протяжении нескольких десятилетий характер острой угрозы государственному суверенитету носят устойчивое функционирование вооруженного бандподполья на территории Северо-Кавказского региона (СКР) и попытки переноса террористической деятельности в другие регионы Российской Федерации.

Основными факторами, детерминирующими террористическую деятельность в регионе, являются:

- наличие организационного ядра, структурных звеньев и пособнических сетей незаконных вооруженных формирований (далее - НВФ);

- активная вербовочная работа эмиссаров террористического бандподполья и использование информационно-пропагандистской инфраструктуры сети Интернет в террористических и иных экстремистских целях;

- возвращение из мест лишения свободы лиц, осужденных за совершение преступлений террористического характера и вынашивающих намерения по продолжению преступной деятельности;

- возвращение граждан, принимавших участие в вооруженных конфликтах за рубежом либо проходивших (проходящих) обучение в тренировочных лагерях боевиков в афгано-пакистанской зоне, Сирии и Ираке;

- разрастание масштабов незаконного оборота оружия, боеприпасов, взрывчатых веществ, взрывных устройств, а также анонимных угроз совершения терактов;

- массовая безработица среди местного населения и иждивенческие настроения в молодежной среде;

- арабизация СКР, используемая салафитскими идеологами для пропаганды религиозного экстремизма;

- высокий уровень коррупции в органах государственной власти и управления.

Тактика деятельности НВФ СКР адаптируется к динамике оперативной обстановки и специфике применяемых правоохранительными органами сил, средств, форм и методов работы. Банддвижение способно достаточно быстро восстанавливать конспиративную систему координации террористической деятельности, нарушенную после нейтрализации бандглаварей различного уровня.

Угрозой государственному суверенитету следует считать длительное отсутствие объединяю- щей многонациональную страну государственной идеологии.

К числу угрозообразующих факторов можно отнести:

- постепенную деградацию системы государственного образования, проявляющуюся в вытеснении бесплатных услуг платными, снижении доступности вузовского и послевузовского образования;

- длительное отсутствие программ государственного патриотического воспитания;

- пропаганду индивидуализма, корыстолюбия и потребительского образа жизни;

- засилье прозападной массовой культуры;

- популяризацию насилия и бездуховности в СМИ;

- отсутствие общегосударственных и региональных «мобилизационных» проектов.

Существенную опасность представляют внешние угрозы, проявляющиеся как процессы ограничения, ослабления или подрыва государственного суверенитета извне.

В настоящее время наиболее острой внешней угрозой является агрессивная политика США и их союзников в отношении России, которая проявляется в:

- развязывании гонки вооружений, милитаризации околоземного комического пространства, модернизации и развертывании системы ПРО;

- инспирировании дальнейшего расширения НАТО относительно государственной границы Российской Федерации;

- стимулировании провокаций, вооруженных конфликтов и очагов нестабильности в приграничных регионах и сопредельных с Россией государствах;

- попытках смены государственно-политического режима в России;

- дискредитации России и демонизации руководства страны средствами пропаганды;

- организации недружественных коалиций и международной изоляции России;

- разрушении интеграционных связей с Украиной, членами ЕС, СНГ, ЕврАзЭС, ОДКБ и др;

- попытках недопущения диверсификации российской экономики и развития ее стратегически важных отраслей;

- наращивании санкционного давления и стремлении нанести максимальный экономический ущерб.

Вашингтон не меняет агрессивного характера своей внешней политики, направленной на ослабление международных позиций России и поддержание очагов напряженности вблизи наших границ. Отказавшись от размещения на территории Польши и Чехии элементов стратегической системы ПРО, Соединенные Штаты приступили к реализации планов ее раз- 
мещения в Азиатско-Тихоокеанском регионе и модернизации с учетом вариантов морского базирования. Североатлантический альянс последовательно расширяет свои функции и зону ответственности. Все отчетливее просматривается его стремление создать так называемый «буфер безопасности» между ЕС и Россией.

Соединенные Штаты стремятся любой ценой сохранить за собой статус единственной сверхдержавы. Американское руководство сделало ставку на поиск нового врага, угроза со стороны которого способна сплотить вокруг США как западных, так и восточных союзников. В настоящее время в качестве подобной угрозы рассматривается деятельность российского руководства. В связи с этим внешняя политика Вашингтона направлена на смену государственно-политического режима в Российской Федерации.

Фактор «нарастающей российской угрозы» Белый дом задействует также в интересах преодоления противоречий внутри НАТО. Главная цель заключается в том, чтобы добиться согласия союзников на существенное увеличение военных расходов, обеспечить постоянное присутствие ВС США в странах Восточной Европы и Балтии, продолжить планомерное приближение военной инфраструктуры блока к государственным границам Российской Федерации ${ }^{11}$.

Удобным предлогом для достижения поставленных целей послужила возникшая в результате многолетних целенаправленных усилий США кризисная ситуация вокруг Украины. В ней отчетливо проявились попытки Вашингтона дискредитировать Россию в глазах Европы, максимально разрушить ее связи с европейскими государствами, лишить стороны выгод и преимуществ тесного взаимодействия, а также вытеснить с европейского рынка российские энергоносители и обеспечить условия для продвижения на нем интересов американских энергетических компаний ${ }^{12}$.

Следует отметить, что обладание энергетическими ресурсами является важнейшим фактором риска ограничения или полной утраты суверенитета для государства. Концептуальную модель подобного посягательства описал В. А. Лебедев: «Если государство, обладающее энергетическими ресурсами, ослаблено, это генерирует попытки со стороны государств, потребление энергии которыми находится на высоком уровне, присвоить эти ценности либо обеспечить к ним доступ на льготных для себя условиях. Для этого применяется политическое лоббирование, попытки приобретения влия-

\footnotetext{
11 Молчанов Г. Военно-политическая обстановка в различных регионах мира // Зарубежное военное обозрение. 2015. № 1. С. 3.

12 Молчанов Г. Там же. С. 3.
}

ния на общественные объединения, в том числе и на политические партии, в целях вмешательства во внутренние дела государства. Именно таким вмешательством может быть объяснено существование атрибутивных, символических государств, т. е. тех, которые, обладая формальными атрибутами государственной власти, экономической, политической и идеологической самостоятельности не имеют. Фактически многие народы обладают лишь исполнительными государствами, которые, осуществляя в том числе и законодательную деятельность, исполняют политические решения других государств»13.

В этом плане Российская Федерация, обладающая обширными углеводородными запасами и геополитическими рычагами влияния на постсоветском пространстве, представляет собой зону особой заинтересованности Вашингтона. Наличие значительной по площади неконтролируемой Соединенными Штатами территории с самостоятельным аппаратом власти, стратегическими отраслями экономики и боеспособными вооруженными силами создает Вашингтону проблемы, связанные с завоеванием мирового господства.

Существенной внешней угрозой являются территориальные претензии ряда иностранных государств к Российской Федерации, в связи с которыми угрозообразующими факторами выступают:

- незавершенность международно-правового оформления государственной границы Российской Федерации с отдельными сопредельными государствами;

- наличие вооруженных конфликтов вблизи государственной границы России (стремление украинского руководства к расширению масштабов карательной операции против Юго-Востока, неопределенность статуса ДНР и ЛНР);

- лоббирование необходимости отторжения от России отдельных ее территорий (островов Курильской гряды, Республики Крым);

- использование неопределенного статуса континентального шельфа в борьбе за Арктическую зону.

Заметную угрозу представляет деятельность координируемых из-за рубежа экстремистских объединений и террористических организаций, направленная на нарушение территориальной целостности, создание сепаратистских анклавов, территорий с «шариатским» правлением, формирование этнически и конфессионально однородных регионов, ликвидацию конституционных органов власти и управления, дестабилизацию социально-политической обстановки в стране.

\footnotetext{
13 Лебедев В. А. Российская демократия: национальные особенности, проблемы и решения в глобализирующемся мире // Гражданин. Выборы. Власть. 2014. № 2. С. 101.
} 
Факторами, способствующими росту данной угрозы, являются:

- инспирирование антигосударственными силами сепаратистских настроений в среде национальных землячеств и диаспор ${ }^{14}$;

- рост влияния ультраправых националистов, пропагандирующих призывы к построению этнически однородного общества;

- расширение географии террористической деятельности международных террористических организаций и экстремистских объединений антироссийской направленности;

- популяризация экстремистских и террористических идей, рост численности неофитов, придерживающихся радикальных взглядов;

- устойчивое функционирование опорной и транзитной инфраструктуры переправки боевиков, возвращение в страну лиц, получивших передовой опыт осуществления террористической деятельности за рубежом.

Значительную опасность представляет слабо контролируемая внешняя миграция.

С учетом масштаба рынка труда мигрантов в Российской Федерации и сращивания национальных анклавов с криминальными структурами нелегальная рабочая сила стала неотъемлемой частью организованного преступного бизнеса. Под влиянием роста численности этнических диаспор, пополняемых за счет мигрантов, происходит вытеснение коренного населения с рынков труда и формируются предпосылки к возникновению межэтнических и межконфессиональных конфликтов. Неконтролируемый приток иностранцев негативно влияет на криминогенную обстановку в крупных административных и промышленных центрах, серьезно меняет национальный состав населения ряда регионов страны и ставит под угрозу этническую, культурную и территориальную целостность Российской Федерации. Отмечается тенденция проникновения в нашу страну по каналам миграции членов международных экстремистских объединений и террористических организаций.

Реализации рассматриваемой угрозы способствует наличие ряда факторов, к числу которых следует отнести:

\footnotetext{
14 Отмечается деятельность пантюркистских организаций по инициированию сепаратистских проявлений со стороны тюркоязычных диаспор (азербайджанской, узбекской, киргизской, казахской, турецко-месхетинской и др.) в субъектах Российской Федерации с преимущественным проживанием тюркоязычного населения, а также инициированию «реформирования» государственного устройства Российской Федерации в целях создания различных форм тюркской национальной государственности для последующего отделения от России. Следует также обратить внимание на попытки использования черкесскими кланами в борьбе за политическое и экономическое влияние адыго-черкесской сепаратистской проблематики.
}

- техническую необустроенность и незавершенность договорно-правового оформления значительных участков государственной границы Российской Федерации с государствами СНГ;

- проявления коррупции в субъектах государственной миграционной политики, способствующие незаконной миграции в Российской Федерации;

- упрощенный порядок въезда на территорию Российской Федерации граждан некоторых иностранных государств;

- значительно более низкий уровень жизни в сопредельных с Россией государствах (за исключением США и государств ЕС);

- ориентацию работодателей на массовое привлечение дешевой рабочей силы за счет трудовых мигрантов;

- нежелание приезжих интегрироваться в социальную структуру российского общества, уважать традиции и культуру коренного населения;

- репрессивную политику ряда государств СНГ, направленную на выдавливание экстремистов и террористов за пределы своей территории;

- несовершенство системы миграционного учета и контроля за въездом, выездом и пребыванием иностранных граждан и лиц без гражданства на территории Российской Федерации.

Как уже отмечалось, деструктивная деятельность антигосударственных сил по ослаблению и подрыву государственного суверенитета нуждается в легитимности, теоретическом обосновании и информационно-пропагандистском обеспечении. С учетом этого представляет интерес типовая аргументация, используемая в целях обоснования ослабления и подрыва государственного суверенитета.

Внешнее посягательство на суверенитет, как правило, осуществляется под предлогом необходимости «защиты демократии» и «борьбы с диктаторскими режимами». Руководство США и стран-сателлитов заявляет в подобных ситуациях о содействии эталонной, подлинной, классической демократии, демократических стандартах и ценностях, позиционируя себя на международной арене как их единственного носителя и выразителя. При этом насильственное распространение «демократии» является основным вектором их внешней политики.

Рассматривая такое обоснование нарушения суверенитета, С. А. Авакьян отмечает, что «периодически одни страны выдают свои представления о демократическом правлении, о справедливом строе за идеальные, желают, чтобы другие страны следовали их моделям, либо навязывают их внешним принуждением. А если не убеждает модель, то можно заявить об угрозе для своей обороны. Таким образом признание и за мировым сообществом, и за отдельными странами каких-то исключительных прав и приоритета 
перед государственным суверенитетом других стран - это очень опасная идея» 15 .

С этой точкой зрения солидарен О. В. Дамаскин: «Тезис о том, что демократия неполноценна, пока в ней не создано гражданское общество по американскому образцу, представляется не только ошибочным, но и опасным. Вера в гражданское общество не должна выражаться в нетерпимости по отношению к демократиям, которые устроены по-другому, что позволяет признать понятие суверенной демократии» 16 .

В ряде случаев для ограничения суверенитета извне используется предлог «борьбы с терроризмом». В результате политики США и их союзников, направленной на усиление своего влияния на Ближнем Востоке, в условиях жесткой конкуренции за доступ к ресурсам и рынкам их сбыта «борьба с терроризмом» становится одним из инструментов решения геополитических и экономических задач. В течение длительного времени Соединенные Штаты проводят комплекс дипломатических, экономических, информационно-пропагандистских, военных и иных мероприятий в целях установления контроля над странами так называемого Большого Ближнего Востока (от Афганистана, Пакистана до Марокко). По этой причине заявленная антитеррористическая борьба постепенно перемещается в другие страны (Афганистан, Пакистан, Ирак, Ливия, Сирия и др.)

Проблема защиты государственного суверенитета в современных условиях неразрывно связана с трансформацией принципа верховенства международного права, который подразумевает уступку государством части национальных суверенных полномочий международной организации. На фоне продолжающейся девальвации международно-правовых норм, усиления зависимости международных институтов от политической воли США и их сателлитов, избирательного соблюдения ими норм международного права, подмены гуманитарных международно-правовых аспектов военно-политическими одностороннее соблюдение международных обязательств означает согласие государства на вмешательство в свои внутренние дела и ущемление национальных интересов.

В связи с этим необходимо разделять тенденции ограничения суверенитета вследствие объективных процессов глобализации и вследствие целенаправленной деятельности ряда иностранных государств и их военно-политических блоков.

В результате развития процессов глобализации на национальном уровне образуется не-

\footnotetext{
15 Авакьян С. А. Указ. соч.

16 Дамаскин О. В. Россия в современном мире: проблемы национальной безопасности. М.: Наука, 2007. С. 47.
}

кий властный вакуум, куда тут же устремляются многочисленные и постоянно усиливающиеся наднациональные центры влияния. Речь идет о разнообразных межгосударственных альянсах (во многих из которых ведущую роль играют США), транснациональных корпорациях, международных клерикальных объединениях, криминальных структурах и террористических организациях и т. д. А. Д. Керимов справедливо указывает на две связанные с этим серьезные проблемы ${ }^{17}$.

Во-первых, названные и другие центры влияния далеко не всегда заботятся о всеобщем благе, а зачастую преследуют собственные эгоистические, порой преступные интересы. «Складывающаяся сегодня инфраструктура глобальной власти сочетается с традиционными мотивами использования власти в угоду тем, кто получил в свои руки ее рычаги. Здесь власть складывается по принципу соотношения сил (в частности, по итогам „холодной войны“) и не может считаться ни демократической, ни легитимной. Coвсем не случайно в последнее время наметилась опасная тенденция подмены международных организаций универсального характера - OOH, Совета Безопасности, ОБСЕ - инстанциями блокового типа, выражающими волю и интересы отдельных стран и группировок, претендующих на особые права. Все это отражает тенденцию присвоения новых возможностей, вытекающих из глобализации власти, не в интересах мирового сообщества, а в интересах сильных и преуспевших»18.

Во-вторых, наднациональные центры влияния берут на себя властные функции и полномочия, а государства утрачивают власть там, где это нецелесообразно и даже вредно с точки зрения достижения и отстаивания как ближайших, так и перспективных целей и интересов всего человечества, обеспечения прав и свобод отдельной личности. Во многих случаях при решении значительного числа жизненно важных вопросов национальная власть остается незаменимой, и ее дефицит, тем более капитуляция перед натиском власти глобальной, несет в себе реальную угрозу наступления деструктивных и регрессивных по своей сути и характеру последствий. Множество процессов и проблем гораздо эффективнее регулируются и решаются на национальном, региональном, местном, а отнюдь не на мировом уровне ${ }^{19}$.

Наибольшую опасность для суверенной государственности представляет целенаправленная деструктивная деятельность иностранных

\footnotetext{
17 Керимов А. Д. Указ. соч. С. 77.

18 Панарин А. С. Россия в циклах мировой истории.

М.: Изд-во МГУ, 1999. С. 283.

19 Керимов А. Д. Указ. соч. С. 78.
} 
государств и их военно-политических блоков по реализации конкретных механизмов ослабления и подрыва государственного суверенитета стран-противников.

В настоящее время среди таких механизмов можно назвать следующие:

1. Экономические санкции, блокады и эмбарго.

2. «Цветные» революции.

3. Тайная политическая, информационная, материально-техническая и финансовая поддержка сепаратистских и иных антигосударственных сил.

4. «Гуманитарные» интервенции.

5. Открытое военное вторжение, организованная вооруженная борьба.

Данные механизмы могут применяться самостоятельно, а также реализовываться в комплексе.

Экономические санкции, блокады и эмбарго применительно к теме исследования применяются с целью нанесения материального ущерба и подрыва экономической основы суверенитета государства-противника.

Как представляется, следует различать международные санкции как меру ответственности государства - нарушителя норм международного права и санкции крупных держав как механизм ослабления и подрыва государственного суверенитета, смены политического режима в странах-противниках.

Международные санкции применяются СБ $\mathrm{OOH}$ в отношении государств, нарушающих нормы международного права (например, аннексия Ираком территории Кувейта в 1990 г., геноцид в Руанде в 1994 г. и др.). Перед введением международных санкций обязательно должны быть использованы все возможные средства и способы урегулирования. Кроме того, международные санкции предполагают точечный характер: наложение ареста на зарубежные активы должностных лиц, ограничение доступа к иностранным финансовым рынкам, эмбарго на поставки оружия и др.

Санкции как механизм ослабления и подрыва государственного суверенитета не имеют международно-правовых оснований и поддержки СБ ООН. Их введение не связано с предварительным использованием примирительных процедур. Сфера действия носит масштабный характер и имеет тенденцию к непропорциональному расширению в целях нанесения максимального материального ущерба противнику.

Применение санкций, блокад и эмбарго в качестве механизма ослабления и подрыва государственного суверенитета имеет давнюю историю.

Так, в 1917-1923 гг. страны Антанты ввели экономическую блокаду (блокирование транспортных каналов) Советской России и запретили любые экономические связи с Советским государством.
В 1960 г. режим эмбарго (полного прекращения торговли) был введен США в отношении Кубы. Предусматривались задержание судов, грузов, иного имущества и запрет захода судов Кубы в порты Соединенных Штатов. В 1985 г. США объявили об экономической блокаде Никарагуа (продолжалась до 1990 г.)

В 2006 г. после победы партии «Хамас» на парламентских выборах США и Евросоюз ввели экономические санкции против Палестинской национальной администрации.

В 2014 г. крупномасштабная санкционная кампания была развязана Соединенными Штатами и Евросоюзом в отношении России после проведения референдума в Крыму и принятия в состав Российской Федерации новых субъектов.

Одним из новейших механизмов ослабления государственного суверенитета являются «цветные» революции, которые предусматривают дезорганизацию функционирования легитимных органов государственной власти, осуществление контроля за формированием новых выборных и назначаемых институтов власти в «демократически недоразвитых странах».

Несмотря на некоторые особенности в ряде государств, «цветные» революции имеют ряд характерных признаков.

Во-первых, аналогичный состав субъектов управляющего воздействия на политический процесс. Как правило, ключевая роль принадлежит международным неправительственным организациям (Фонд Сороса, Национальный фонд поддержки демократии, Freedom House). Эти структуры негласно финансируют интересующих их кандидатов и политические партии, обучают активистов для участия в акциях протеста, оказывают методическую помощь отдельным избирательным штабам, консультируют кандидатов и их доверенных лиц, оказывают давление на иностранных и международных наблюдателей.

Международные неправительственные организации и представители оппозиции активно используют студенческие организации в качестве мобильных и радикально настроенных участников «революционных» событий. Так, выдающуюся роль в агитации против С. Милошевича и организации массовых беспорядков на улицах Белграда в 2000 г. сыграла студенческая организация «Отпор». Организатором массовых акций в Грузии в 2003 г. выступила радикальная студенческая организация «Кмара». В 2004-2005 гг. в Украине действовала студенческая организация «Пора», инициировавшая акции протеста на Майдане.

Во-вторых, общим признаком «цветных» революций является применение схожих технологий оппозиционной борьбы. Можно назвать их «катализирующими» технологиями, 
поскольку их использование направлено на обострение социально-политической ситуации в стране, вовлечение в политическую борьбу максимального количества участников, привлечение внимания мировой общественности к происходящим событиям. Используемые для этого противоправные действия (несанкционированные митинги, захваты и блокирование государственных органов, организация массовых беспорядков, создание незаконных военизированных формирований, вмешательство в работу избирательных комиссий и т. п.), как правило, остаются безнаказанными, поскольку имеют выраженную политическую окраску и осуществляются под прикрытием оппозиционной борьбы. Первостепенное значение имеет постоянная пропаганда оппозиционной правящему политическому режиму идеологии. Возможен захват организаций телевидения и радиовещания.

B-третьих, для захвата политической власти и смены государственно-политического режима применяется так называемое «внешнее голосование» 20 . В избирательном процессе данная технология используется при повторном голосовании или после официального объявления итогов выборов в случае незначительного перевеса голосов, поданных за того или иного кандидата. Полученный перевес можно объяснить массовыми нарушениями, допущенными кандидатом-оппонентом, официально обжаловать их в суд и обратиться к мировой общественности (в лице США и ЕС) с просьбой о непризнании итогов выборов. Если поводом для «цветной» революции стало иное общественно значимое событие (например, решение правительства Украины о приостановке подготовки к подписанию Соглашения об ассоциации между Украиной и ЕС в ноябре 2013 г.), антигосударственные силы обращаются к иностранным субъектам с просьбой о помощи «демократическим» силам в евроинтеграции, поддержке в «борьбе с тиранией» и коррумпированным режимом и др.

В отличие от «цветных» революций, являющихся инновациями политической подрывной работы, в которых иностранное участие не маскируется, тайная политическая, информационная, материально-техническая и финансовая поддержка сепаратистских и иных антигосударственных сил как механизм ослабления и подрыва государственного суверенитета традиционно и на протяжении длительного времени используется в конспиративной враждебной деятельности иностранных государств.

Так, сразу после Октябрьской революции 1917 г. британский кабинет министров, обсуж-

20 См.: Кара-Мурза С. Г. Экспорт революции. Ющенко, Саакашвили... М.: Алгоритм, 2005. С. 254, 260. дая политику в отношении советской власти, высказался за финансовую и иную поддержку любых антисоветских сил при условии, если последние «дадут гарантию следовать в фарватере политики союзников». Английскому послу в России Джорджу Бьюкенену было разрешено истратить около 10 млн руб. на развитие контрреволюционного движения в России ${ }^{21}$.

Одним из ярких свидетельств тайной деструктивной деятельности по ослаблению и подрыву государственного суверенитета Coветской России с использованием диверсионно-террористических методов со стороны британского и французского правительств стал «заговор послов». После разоблачения заговора народный комиссар по иностранным делам Г. В. Чичерин 7 сентября 1918 г. заявил: «Дипломатические и военные представители Англии и Франции пользуются своим званием для организации на территории РСФСР заговоров, направленных к захвату Совета Народных Комиссаров с помощью подкупа и агитации среди войсковых частей, к взрыву мостов, продовольственных складов и поездов. Данные (...) устанавливают с несомненностью тот факт, что нити заговора сходились в руках главы английской миссии Локкарта и его агентов. Равным образом установлено, что здание английского посольства в Петрограде фактически было превращено в конспиративную квартиру заговорщиков (...). Поэтому правительство РСФСР поставлено в необходимость создать для лиц, уличенных в заговорах, такие условия, при которых они были бы лишены возможности продолжать (...) свою преступную, с точки зрения международного права, деятельность» 22 .

В 1921 г. крупнейшей антисоветской организацией за рубежом стал «Народный союз защиты родины и свободы», который был сформирован при содействии польских властей и представителей французской военной миссии в Варшаве. Фактически «Союз» стал подсобным органом польской разведки.

В докладе ВЧК о деятельности «Народного союза защиты родины и свободы» говорилось: «Роль польского генерального штаба сводится к следующему: а) разрешению и содействию организации на территории Польши партизанских отрядов и перевозке их по железной дороге за счет польского военного министерства; б) снабжению этих отрядов оружием; в) содействию вербовке в лагерях военнопленных и интернированных организаторов антисоветских групп и отправке их в Россию; г) содей-

21 Голинков Д. Л. Крушение антисоветского подполья в СССР. М.: Изд-во политической литературы, 1986. Кн. 1. C. 123.

22 Международная политика новейшего времени в договорах, нотах и декларациях. М., 1926. Ч. 2. С. 170. 
ствию реорганизации и приведению в боевую готовность остатков интернированных армий Булак-Балаховича, Перемыкина и Петлюры» 23.

Тайная антигосударственная деятельность проводилась не только в отношении Советской России и СССР. Вашингтон и его союзники предпринимали неоднократные попытки свержения социалистических и революционных правительств по всему миру 24 .

Так, после победы революционных сил в Никарагуа правительство США в 1980-е гг. начало оказывать поддержку никарагуанским контрреволюционерам («контрас»), предоставлять им вооружение, инструкторов и материальную помощь для свержения сандинистского режима. В тот период Вашингтон ежегодно ассигновал на военно-материальную помощь «контрас» до 100 млн долл. Дополнительно оказывалась поддержка по неофициальным каналам. В 1985 г. в ответ на агрессивные действия США военную помощь Никарагуа предоставили СССР и Куба.

Эффективным механизмом ослабления и подрыва государственного суверенитета, подмены гуманитарных международно-правовых аспектов военно-политическими являются так называемые «гуманитарные» интервенции. Современная концепция «гуманитарных» интервенций предполагает применение вооруженных сил против государств, нарушающих права человека, без разрешения Совета Безопасности $\mathrm{OOH}$ и согласия законного правительства данного государства. С юридической точки зрения, отсутствие мандата ООН характеризует любые «гуманитарные» интервенции как военную агрессию25.

В мае 2010 г., выступая перед офицерами военной академии (Вест-Пойнт), Президент США Б. Обама заявил: «Соединенные Штаты будут использовать военную силу и в одностороннем порядке, если это необходимо, когда наши интересы потребуют этого - когда угрожают нашим людям, когда речь идет о наших жизнях, когда безопасность наших союзников в опасности. (...) Международное мнение имеет значение,

\footnotetext{
23 Голинков Д. Л. Указ. соч. С. 128-129.

24 В свою очередь СССР и страны социалистического лагеря активно участвовали в антиколониальных войнах 1960-1970-х гг. В частности, повстанцы Анголы, Гвинеи-Бисау и Мозамбика получали военную поддержку от СССР и Китая.

25 В связи с действиями США по поддержке никарагуанских «контрас» Международный суд $\mathrm{OOH}$ в деле «Республика Никарагуа против Соединенных Штатов Америки» указал, что международное право не санкционирует использование государством вооруженной силы для исправления ситуации с серьезными нарушениями в области прав человека в другом государстве без одобрения Совета Безопасности ООН. The Republic of Nicaragua v. The United States of America (1986) / International Court of Justice.
}

но Америка никогда не должна испрашивать разрешения на то, чтобы защищать своих людей, свою родину и свой образ жизни».

Таким образом, американским политическим руководством на высшем уровне была заявлена готовность начинать и проводить военные действия по собственному усмотрению, не запрашивая санкции Совета Безопасности $\mathrm{OOH}$.

Следует отметить, что Соединенные Штаты и их военно-политические союзники по блоку НАТО давно занимают лидирующие позиции в апробации и легализации механизма «гуманитарных» интервенций.

Вторжение США в Панаму в 1989 г. в целях смены правящего режима, стремящегося проводить независимый от Вашингтона политический курс, является первой в истории «гуманитарной» интервенцией Соединенных Штатов, для обоснования которой использовались лозунги «восстановления демократии». В результате вторжения США правительство Панамы было свергнуто.

Первой крупномасштабной военной акцией НАТО стала операция «Обдуманная сила» (август - сентябрь 1995 г.). «Гуманитарная» интервенция НАТО сыграла значимую роль в поражении сербов в Боснии и заставила их руководство подписать Дейтонские соглашения в декабре 1995 г. В 1999 г. силами НАТО против Союзной Республики Югославия была проведена очередная «гуманитарная» интервенция (операция «Союзная сила»). В качестве предлога для военной агрессии были названы этнические «чистки» в Косово.

В 2001 г. с целью свержения режима талибов вооруженные силы США вторглись в Афганистан. Декларируемые цели военной интервенции были достигнуты.

В 2003 г. с целью свержения правительства Саддама Хусейна Соединенные Штаты и страны-союзники начали военную операцию против Ирака. Официальными поводами к началу военных действий были заявлены связь правящего режима с международным терроризмом и поиск оружия массового поражения. Результатом «гуманитарной» интервенции стали смена власти в Ираке и установление американского контроля над нефтяными месторождениями.

В 2008 г. Российская Федерация впервые применила механизм «гуманитарной» интервенции при проведении операции по разъединению враждующих сторон и принуждению Грузии к миру для защиты миротворческого контингента и своих граждан, проживающих в зоне грузино-юго-осетинского конфликта. Однако, в отличие от операций США и блока НАТО, конфликт был локализован на ограниченной территории, применение Вооруженных 
сил Российской Федерации носило пропорциональный характер и не преследовало цель смены правящего в Грузии политического режима.

В августе 2014 г. под предлогом защиты национальных меньшинств в Ираке Вашингтон санкционировал проведение в Ближневосточном регионе военной операции «Непоколебимая решимость» против террористической организации «Исламское государство» и приступил к нанесению ракетно-бомбовых ударов по Ираку. В сентябре было принято решение о расширении масштабов операции и нанесении ударов по территории Сирии.

Учитывая низкую эффективность воздушных ударов по мобильным группам боевиков «Исламского государства», в настоящее время США предпринимают меры по созданию наземной группировки. Планируемая операция позволяет легитимизировать использование против Дамаска военной силы, а затем свергнуть правительство Б. Асада ${ }^{26}$.

Анализ обстановки в регионе свидетельствует, что фактически под вывеской борьбы с террористической группировкой «Исламское государство» началась скрытая фаза агрессии против Сирии. США создают удобный повод для переноса ударов по правительственным войскам самой Сирии, после чего любое недовольство Б. Асада действиями США можно расценивать как пособничество террористам.

Наиболее острый и непримиримый характер имеет механизм открытого военного вторжения, организованной вооруженной борьбы. Данный механизм предполагает применение крайних мер воздействия на государство-противника. В отличие от «гуманитарных» интервенций открытое военное вторжение даже не маскируется необходимостью «защиты прав человека», «борьбы с международным терроризмом» и «демократизации». Применение военных мер на практике ведет только к расширению конфликтного пространства и провоцирует дальнейшую напряженность. Поэтому в современных условиях данный механизм официально применяется крайне редко.

Одной из крупномасштабных войн, развязанных «Объединенной Европой» против России, стало нападение Наполеона на Российскую империю. Агрессивная политика Наполеона в отношении европейских государств, проводимая без учета интересов России, уверенность в продолжении серии военных успехов Франции, отказ России от континентальной блокады Великобритании послужили причинами военного вторжения армии Французской империи в Россию. Стратегический расчет французского командования был связан с разгромом русской армии в генераль-

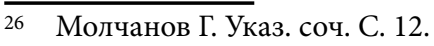

ном сражении, подписанием мирного договора и завершением кампании в Смоленске и Минске. Однако в Отечественной войне 1812 г. русская армия не только отстояла независимость России, но и в ходе контрнаступления нанесла решительное поражение французским войскам, а затем в ходе преследования довершила их разгром.

Из всех войн начала эпохи империализма наиболее значительной была Первая мировая война. Борьба за колонии, столкновение торгово-экономических интересов «великих» держав (Германии и Великобритании, Германии и Франции, Германии и России, России и Австро-Венгрии) стали причинами Первой мировой войны.

Война была наиболее выгодна американским империалистам, поскольку она привела к ослаблению всех европейских государств и тем самым способствовала стремлению правящих кругов США к мировому господству.

После победы Октябрьской революции в России, как уже отмечалось, крупнейшие империалистические государства начали открытую дипломатическую, экономическую, а затем и вооруженную борьбу с Советской республикой. В годы становления советской власти и Гражданской войны правящие круги Великобритании, США, Франции, Германии и Японии, рассчитывающие на расчленение России и ликвидацию советского политического режима, осуществили открытое военное вторжение на территорию России. В марте 1918 г. в Мурманске высадились английские и французские войска, в апреле Владивосток захватили японские, английские, американские и французские воинские части. 2 августа англичане захватили Архангельск, а 4 августа - Баку.

Пользуясь тяжелым положением России, немцы весной и летом 1918 г. оккупировали Грузию, Крым, Новороссийск, Таганрог, Ростов, вторглись в Донскую область. Союзница Германии Турция захватила Армению. В декабре 1918 г. финские войска захватили ряд пограничных волостей в советской Карелии.

Открытые военные интервенции дополнялись всеми формами поддержки антигосударственных сил. При поддержке иностранных интервентов на территории бывшей Российской империи образовывались антисоветские «правительства». На оккупированных территориях формировались монархические и националистические организации и воинские подразделения, которые при содействии и помощи иностранного военного командования забрасывались в советский тыл и вели там подрывную работу, нападая на красноармейские части ${ }^{27}$.

В 1941 г. Германия в целях подрыва государственного суверенитета СССР на пути 
к завоеванию мирового господства осуществила вероломное нападение на Советский Союз. Идеологически нападение нацистской Германии на Советский Союз обосновывалось концепцией «Lebensraum» («Жизненного пространства») немцев.

В Приложении № 2 к Приказу командующего 4-й танковой группой в связи с предстоящими боевыми действиями на Востоке отмечалось: «Война против России является важнейшей частью борьбы за существование немецкого народа. Это - давняя борьба германцев против славян, защита европейской культуры от московско-азиатского нашествия, отпор еврейскому большевизму. Эта борьба должна преследовать цель превратить в руины сегодняшнюю Россию, и поэтому она должна вестись с неслыханной жестокостью. Каждый бой должен быть организован и проводиться с железной волей, направленной на безжалостное и полное уничтожение противника»28.

Важнейшей политической задачей Германии и ее союзников было в кратчайший срок добиться военного поражения СССР как главного условия реализации планов мирового господства. В своих расчетах гитлеровское командование исходило из организации внезапного удара и стратегии тотальной и «молниеносной» войны, теория которой предусматривала достижение быстрой и полной победы над противником в одной кампании, чему должна содействовать внезапность нападения.

Руководители фашистской Германии разработали целую систему мероприятий по политическому, экономическому и идеологическому закабалению народов СССР, физическому истреблению значительной части советских людей, что нашло свое выражение в заблаговременно утвержденном высшими политическими и военными инстанциями Германии генеральном плане «Ост».

В 1960-х гг. в целях ликвидации зоны советского влияния на Кубе и подрыва суверенитета Республики Куба механизмы организованной вооруженной борьбы активно применялись Соединенными Штатами. Так, в апреле 1961 г. кубинские эмигранты при поддержке ЦРУ и МО США высадили вооруженный десант в заливе Свиней с целью спровоцировать массовое восстание против социалистического правительства Кубы (операция «Запата»). Однако вооруженная интервенция не нашла поддержки среди населения и была успешно пресечена Революционными вооруженными силами Кубы. В 1962 г. МО США спланировало очередное вооруженное вторжение на Остров Свободы и свер-

28 Преступные цели гитлеровской Германии в войне против Советского Союза: Документы и материалы. М.: Воениздат, 1987. С. 62. жение правительства Фиделя Кастро (операция «Нортвудс»). Операция предполагала осуществление террористических актов на территории Кубы, США и других стран, имитацию враждебных действий под иностранным флагом, угоны самолетов ${ }^{29}$.

Только в 1986 г. американские историки официально признали, что операция США в 1961 г. являлась вооруженным вмешательством во внутренние дела иностранного государства и актом агрессии США против Кубы ${ }^{30}$.

Наиболее известной вооруженной интервенцией США стала военная кампания во Вьетнаме (1965-1973 гг.), развернутая с целью сдерживания коммунистического движения и поддержки проамериканского режима в Южном Вьетнаме. С 1965 по 1969 г. ВС США проводили крупномасштабные наступательные операции в Южном Вьетнаме, направленные на обнаружение и уничтожение подразделений северовьетнамской армии (стратегия «найти и уничтожить»). В ходе боевых действий ВВС США распыляли токсичные дефолианты над джунглями, что было признано одной из крупнейших акций военного экоцида. Активно применялись фугасные бомбы, напалм, фосфор и другие запрещенные виды вооружений. Происходило массовое уничтожение мирных жителей, хозяйственной инфраструктуры, практиковалось разрушение ирригационных сооружений, приведение сельхозугодий в негодность. Однако длительная военная кампания, не имеющая четких военно-политических целей, повлекшая значительные потери среди военнослужащих ВС США, вызвала массовое антивоенное движение в Соединенных Штатах, которое вынудило американское руководство в 1973 г. вывести свои войска из Вьетнама.

Приведенные примеры свидетельствуют об активном использовании в политическом противоборстве государств всего арсенала механизмов ослабления и подрыва суверенитета стран-противников. Вместе с тем в современных условиях, учитывая информационную открытость общества, массовое распространение информационно-телекоммуникационных систем и средств связи, официальные механизмы открытого военного вторжения вытеснены «гуманитарными» интервенциями либо скрытым введением ограниченных воинских контингентов на территории оперативной заинтересованности.

Следует отметить, что в период существования СССР значительная часть описанных механизмов ослабления и подрыва государственного суве-

29 Сергеев Ф. Тайная война против Кубы. М.: Прогресс, 1982. C. 44, 101.

30 Вопросы истории. 1987. № 7. С. 157-164. 
ренитета иностранных государств, реализуемых США и их союзниками, компенсировалась СССР и странами социалистического лагеря. После распада Советского Союза экспансия США и глобальное доминирование единственной сверхдержавы приобрели неограниченный характер и повлекли крайне негативные последствия. Миропорядок утратил элементы стабильности и предсказуемости. Как и в Средневековье, в мировой политике и межгосударственных отношениях стало господствовать «право сильного».

Проведенное автором исследование угроз государственному суверенитету, факторов и механизмов его ослабления и подрыва позволяет сделать следующие выводы:

1. Суверенитет является динамичной характеристикой государства. Он может быть подорван и утрачен, что влечет за собой снижение качественных характеристик реализации функций государства в наиболее важных сферах общественной жизни или полную утрату способности государства осуществлять самостоятельное управление делами общества и государства. В силу этого государственный суверенитет нуждается в защите.

2. Основанием защиты государственного суверенитета выступает деструктивная деятельность внутригосударственных и зарубежных субъектов по его ослаблению и подрыву, которая формирует реальные угрозы государственному суверенитету.

3. Проводимая руководством США и их союзниками политика глобального доминирования предполагает сохранение на максимально возможный период лидирующей роли Соединенных Штатов с помощью нанесения ущерба суверенным государствам, претендующим на роль центров многополярного мира, для чего в настоящее время используется ряд механизмов ослабления и подрыва их государственного суверенитета: барго

- экономические санкции, блокады и эм-

— «цветные» революции;

— «гуманитарные» интервенции;

- тайная и открытая политическая, информационная, материально-техническая и финансовая поддержка сепаратистских и иных антигосударственных сил;

- открытое военное вторжение, организованная вооруженная борьба.

Реализация данных деструктивных механизмов носит политико-стратегический, долгосрочный характер и не зависит от императивов глав государств и правительств, текущего информационно-пропагандистского фона, экономической конъюнктуры, тактических установок спецслужб и органов внешних сношений.

\section{Список литературы}

1. The Republic of Nicaragua v. The United States of America (1986) / International Court of Justice.

2. Авакьян С. А. Точка отсчета - народ // Российская газета. 2006. 28 октября.

3. Внешняя политика России: теория и практика / Под ред. С. В. Смульского и О. Д. Абрамовой. М.: Книга и бизнес, 2013. С. 147.

4. Вопросы истории. 1987. № 7. С. 157-164.

5. Голинков Д. Л. Крушение антисоветского подполья в СССР. М.: Изд-во полит. лит-ры, 1986. Кн. 1. С. 123; Кн. 2. С. $128,129$.

6. Дамаскин О. В. Коррупция: состояние, причины, противодействие. М.: Триумфальная арка, 2009. C. 32 .

7. Дамаскин О. В. Криминологические аспекты формирования современной уголовно-правовой политики // Современное право. 2013. № 5.

8. Дамаскин О. В. Россия в современном мире: проблемы национальной безопасности. М.: Наука, 2007. C. 47.

9. Кара-Мурза С. Г. Экспорт революции. Ющенко, Саaкашвили... М.: Алгоритм, 2005. С. 254, 260

10. Керимов А. Д. Государственная организация общественной жизнедеятельности. Вопросы теории. М.: Норма, 2014. С. 67-69.

11. Лебедев В. А. Российская демократия: национальные особенности, проблемы и решения в глобализирующемся мире // Гражданин. Выборы. Власть. 2014. № 2. C. 101.

12. Молчанов Г. Военно-политическая обстановка в различных регионах мира // Зарубежное военное обозрение. 2015. №1. С. 3.

13. Панарин А. С. Россия в циклах мировой истории. М.: Изд-во МГУ, 1999. С. 283.

14. Преступные цели гитлеровской Германии в войне против Советского Союза: Документы и материалы. М.: Воениздат, 1987. С. 62.

15. Сергевнин С. Л. Нормоустановление, администрирование и социостабилизация в качестве ипостасей типологии властеотношений // Российский журнал правовых исследований. 2015. № 1 (2). С. 140-141.

16. Сергеев Ф. Тайная война против Кубы. М.: Прогресс, 1982. С. $44,101$.

17. Состояние законности и правопорядка в Российской Федерации и работа органов прокуратуры. 2012 год: информационно-аналитическая записка / Под общ. ред. ректора Академии Генеральной прокуратуры Российской Федерации, д. ю. н., проф. О. С. Капинус. М., 2013. 343 с.

18. Статистические данные ГИАЦ МВД России (форма 494, форма 590). 


\title{
Modern approaches to the theoretical substantiation of protection of state sovereignty
}

\author{
Krasinski V. V., \\ Doctor of Law, Professor, member of the Public \\ the advisory scientific and methodological \\ Council of the CEC of Russia
}

Abstract: In article the actual threats to the state sovereignty and the mechanisms of its easing and blasting are considered. The author analyzes the destructive activities of antistate forces for easing and blasting the state sovereignty and proves the necessity of protection of the state sovereignty.

Keywords: state sovereignty, protection of the state sovereignty, threats to the state sovereignty, factors of easing and blasting the state sovereignty, mechanisms of easing and blasting the state sovereignty, antistate forces.

\section{References:}

1. The Republic of Nicaragua v. The United States of America (1986) / International Court of Justice.

2. Avakyan SA starting point - people // Ros. gaz.Rossiyskaya newspaper, 28 October 2006.

3. Russia’s Foreign Policy: Theory and Practice / Ed. SV Smulsky and OD Abramova. - M.: Book and Business, 2013. 147 pp.

4. Questions of History,. 1987. - № 7. Pp. 157-164.

5. Golinko DL Crash anti-Soviet underground in the USSR. Book 1. - M.: Publishing House watered. literature ryIzdatelstvo political literature, 1986. 123 pp; Book 2, pp 128, 129.

6. Damascus OV corruption: state, causes a reaction. - M.: the Arc de Triomphe, 2009. Pp. 32.

7. Damascus O. Criminological aspects of the formation of modern penal policy // Modern law,. 2013. — № 5.

8. Damascus OV Russia in the modern world: problems of national security. - M.: Nauka, 2007. Pp. 47.

9. Kara-Murza SG Export revolution. Yushchenko, Saakashvili... - M.: Publishing House of the algorithm, 2005, pp 254, 260.

10. Kerimov AD state organization of social life. Questions of the theory. - M.: Norma, 2014. pp 67-69.

11. Lebedev VA Russian Democracy: national features, problems and solutions in a globalizing world // Citizen. Elections. Power,. 2014. — № 2. S. 101.

12. Molchanov, the military-political situation in the various regions of the world // Foreign Military Review,. 2015. — №1. S. 3.

13. A. Panarin Russia in the cycles of world history. Pp. 283.

14. Sergevnin SL Normoustanovlenie, administration and sotsiostabilizatsiya as an incarnation of the typology of power relations // Russian Journal of Legal Studies. 2015. № 1 (2). Pp. 140-141.

15. F. Sergeev secret war against Cuba. - M.: Progress, 1982, pp. 44, 101.

16. The condition of law and order in the Russian Federation and the work of the prosecution. 2012: Informational and analytical note / under total. Ed. Rector of the Academy of the Prosecutor General of the Russian Federation Mr. Dmitry jurid. n.auk, prof. OS Kapinus. - M., 2013. - 343 p.

17. Statistical data MIAC Russian Interior Ministry (Form 494, Form 590). 